\title{
Model Catalyst Performance and Efficiency during the Hydro-treatment of Heavy Oil Residuum
}

\author{
Jamal Mohammad Amous \\ Chemical Engineering Department, Faculty of Engineering, University of Hail, Hail, Kingdom of Saudi Arabia
}

Copyright $\mathrm{C} 2018$ by authors, all rights reserved. Authors agree that this article remains permanently open access under the terms of the Creative Commons Attribution License 4.0 International License

\begin{abstract}
Fixed bed tubular plug flow reactor is used to investigate model catalysts performance during the hydrodesulphurization of Heavy Arabian Oil atmospheric residuum. The effects of temperature $\left(300-380^{\circ} \mathrm{C}\right)$, pressure (30-80 atm) and particle size with characteristic lengths $\left.\left(L p_{o}=0.0059 \mathrm{~cm}\right), \mathrm{Lp}_{1}=0.0327 \mathrm{~cm}\right)$ on the rate of the Hydrodesulphurization reaction are investigated. Supported Co-Mo/ $\gamma-\mathrm{AL}_{2} \mathrm{O}_{3}$ catalysts, CAT -1 with $\mathrm{Co}=$ $3 \mathrm{wt} . \%$ and $\mathrm{Mo}=10.6 \mathrm{wt} . \%$ and $0.5 \mathrm{wt} . \% \mathrm{MS} 13 \mathrm{X}$ and CAT-2 with the same composition but without the addition of MS 13X loadings were prepared using the double impregnation method. All prepared catalysts were characterized for their porous structure and composition. A Kinetic equation was developed for pulverized CAT-1 particles, $\mathrm{R}_{\mathrm{HDS}}=9.9696 * 10^{10} \exp (-17058 / \mathrm{T}) * \mathrm{P}_{\mathrm{H} 2} * \mathrm{C}_{\mathrm{S}}^{2.2} /$ $\left(1+0.00802 * \mathrm{P}_{\mathrm{H} 2}\right)$. Effectiveness factors and effective diffusivity coefficients were estimated for both catalyst particle sizes. CAT-1 catalyst sample showing slightly higher activity lost approximately $20 \%$ of its initial activity after 450 hours of operation compared to $11 \%$ lost for CAT-2 sample. The presence of MS $13 \mathrm{X}$ in CAT-1 is accompanied with lighter $\mathrm{HC}$ products $\left(\mathrm{C}_{1}-\mathrm{C}_{4}\right.$ up to $\left.210^{\circ} \mathrm{C}\right)$ giving rise to more hydrocracking orientations especially at high temperatures with higher API degrees of the treated products.
\end{abstract}

Keywords Catalysts, Hydrodesulphurization, Plug, Back Mixing, Kinetics, Performance, Porous Structure, API Degrees

\section{Introduction}

The last century had been marked by major developments in deep understanding of catalyzed reactions theory and catalyst performance. Most of the produced chemicals have been achieved with the aid of catalysts [1, 2]. One of the major areas of catalyst applications is the hydro treatment of oil producing fractions with lower sulfur, Nitrogen and heavy metals content, thus more pure fractions means more safe applications enabling well-known products and safer fuels to a degree that catalysis have gained an increasing importance and became so irreplaceable in the fight and control of environmental pollution.

Catalyst market shares based on the sales value is shown in Table 1 and those based on the importance of hydro-treating catalysts are shown in Table 2 . Also it must be mentioned that in 1998, the petroleum refining catalyst sales approached $\$ 2.16$ billion [3]. The worldwide market value for catalysts was reported to have a relevant average growth rate (AGR 2003-2009) of 6.1\% [4].

Table 1. The share of each group of catalysts based on the sales value of the world's catalyst production [3]

\begin{tabular}{|c|c|}
\hline Catalyst technology division & Sales value $\%$ \\
\hline Environmental cleanup & 43 \\
\hline Petroleum refining & 30 \\
\hline Chemical production & 27 \\
\hline
\end{tabular}

The cost of catalysts ranges typically from $0.1 \%$ (petroleum refining) to $0.22 \%$ (petrochemicals) of the products value [5], it is estimated that catalysts induce a market of manufactured goods exceeding $\$ 7,500$ billion yearly [6]. This study is concerned with the preparation and testing of hydro treating catalysts with different physical and chemical properties. The effect of the presence of Molecular Sieves S- 13X embedded in the structure of the catalyst on the catalyst performance is also investigated.

\section{Theoretical}

Among all HDS activity studies, one of the most interesting and reasonable is that dealing with heavy residuum treatment because of the composition and complex structure of sulfur and other heteroatoms containing materials(S-, N-, O-organic compounds). The need for oils with very low contents of these elements has become an urgent need under the strict restrictions imposed on the use of petroleum derivatives. Design and operation of chemical reactors for carrying HDS reaction must be 
preceded by investigations on the kinetics and on the reactor \& catalyst performance.

Table 2. Percentage of world's market share of oil refining catalysts

\begin{tabular}{|c|c|}
\hline Refining Catalyst & Percentage \% \\
\hline Fluid catalytic cracking & 45 \\
\hline Hydro treating & 35 \\
\hline Hydrocracking & 8 \\
\hline Reforming & 6 \\
\hline Isomerization & 2 \\
\hline
\end{tabular}

Many studies dealt with the HDS reaction kinetics using different oil residues as reviewed by several authors [7-9] during the past years. Despite the large amount of conducted research there is still debate on both the kinetics and catalyst performance during HDS of these fractions.

Various possibilities of reaction paths for HDS of model sulfur compounds have been proposed by Lipsch and Schuit [10], who investigated the kinetics of Thiophene HDS and reported that the thiophene HDS occurs via direct C-S bond cleavage to form Butadiene intermediate, tetrahydro-thiophene (THT) or dihydro-thiophene(DHT). However, these intermediates are very difficult to observe under standard reaction conditions [11]. Because these species are very reactive, re-adsorption in the pores of the catalysts will convert the main part of these species to C4-species and at the end only the main products are found [11]. In general, residuum HDS kinetics is described by Langmuir-Hinshelwood type of reaction equations with the surface reaction between adsorbed sulfur compounds and adsorbed Hydrogen as rate limiting step [12]. $\mathrm{H}_{2} \mathrm{~S}$ is usually taken as an inhibitor in competition with the sulfur compound itself for the same adsorption sites, although some authors conclude that $\mathrm{S}$ removal can also be rate limiting in some cases. Hydrogen sulfide role is neglected in cases where its concentration is very low. [12].

The adsorption of $\mathrm{H}_{2}$ is assumed to take place on separate sites, although some authors report competition between $\mathrm{H}_{2}$ and sulfur compounds for the same type of site. Van Parijs and Froment [13] reported the existence of two types of active sites on HDS catalysts, i.e. one for Hydrogenolysis and one for hydrogenation. This is in agreement with the Rim Edge model of Daage and Chianelli [14]. Another debate concerns the adsorption mode of hydrogen being either molecularly or dissociative adsorbed.

\section{Experimental}

\subsection{Catalysts}

$\mathrm{Co}-\mathrm{Mo} / \gamma-\mathrm{Al}_{2} \mathrm{O}_{3}$ supported catalysts were prepared by double impregnation technique at room temperature [15, $16,17,18,19$,]. Mo is added in the form of ammonium Hebtamolybdate tetra hydrate $(\mathrm{NH} 4)_{6} \mathrm{Mo}_{7} \mathrm{O}_{24} \cdot 4 \mathrm{H}_{2} \mathrm{O}$ to aqueous solution of Cobalt nitrate hexahydrate $\mathrm{Co}\left(\mathrm{NO}_{3}\right)_{2} \cdot 6 \mathrm{H}_{2} \mathrm{O}$ followed by the addition of pulverized
$\gamma$-Alumina (48 mesh size) to the well mixed solution. "Al-Megren in [20]" proposed different methods for catalyst preparation. Additives are added to the hydro treating catalysts to improve catalyst performance [21]. Molecular sieves MS $13 \mathrm{X}(0.5 \mathrm{wt} . \%)$ is added to the aqueous solution of the different constituents. Then the mixtures are left for 5 hours and excess water is removed and the mixture is extruded into $1.58 \mathrm{~mm}$ cylindrical particles in diameter and $3.5 \mathrm{~mm}$ in length, dried at $120^{\circ} \mathrm{C}$, and finally calcined at $798 \mathrm{~K}$ for $10 \mathrm{~h}$. The components present in the produced catalyst samples and their weight percentage are listed in Table. 3 .

The main pore structure parameters ( specific surface area, pore volume and most probable diameter determined with $\mathrm{N}_{2}$ adsorption-desorption apparatus and Mercury Porosimetry are listed in Table 3. Sulfidation of these catalysts was carried in sito.

\subsection{Oil Treated}

Oil fractions investigated are Arabian Heavy Crudes residuum with boiling points $<330^{\circ} \mathrm{C}$. The main physical features of these crudes are listed in Table 4.

Table 3. Catalysts chemical composition and main pore structure specifications.

\begin{tabular}{|c|c|c|}
\hline Cat.symb. & CAT 1 & CAT 2 \\
\hline$\gamma-\mathrm{Al}_{2} \mathrm{O}_{3}, \mathrm{Wt} . \%$ & 85.9 & 86.4 \\
\hline $\mathrm{CoO}$, wt. \% & 3 & 3 \\
\hline $\mathrm{MoO}_{3}$, wt.\% & 10.6 & 10.6 \\
\hline $\mathrm{MS} \mathrm{13X,wt. \%}$ & 0.5 & 0 \\
\hline $\mathrm{Sg}, \mathrm{m}^{2} / \mathrm{g}[\mathrm{BET}]$ & 188.2 & 180.6 \\
\hline $\mathrm{Sg}, \mathrm{m}^{2} / \mathrm{g}[\mathrm{MP}]$ & 113.8 & 110.9 \\
\hline $\mathrm{Vp}^{(1)}$ & 0.41 & 0.39 \\
\hline $\mathrm{Vp}^{(2)}$ & 0.32 & 0.34 \\
\hline $\mathrm{dp}^{(1)}$ & 83 & 87 \\
\hline $\mathrm{dp}^{(2)}$ & 123 & 128 \\
\hline$\rho_{\text {obs.bed, }} \mathrm{g} / \mathrm{cm}^{3}$ & 0.78 & 0.75 \\
\hline
\end{tabular}

M.P**: Mercury Penetration(1800 bar), $\mathrm{Vp}^{(1)}$ : Pore volume measured with $\mathrm{N}_{2}$ Ads-Des technique, $\mathrm{Vp}^{(2)}$ : Pore volume measured with mercury penetration, $\mathrm{dp}^{(1)}$ : Most probable pore diameter in Angstrom( $\AA$ )measured with $\mathrm{N}_{2}$ Ads-Des, $\mathrm{dp}^{(2)}$ : Most probable pore diameter in Angstrom $(\AA)$ measured with mercury penetration technique. $\rho_{\text {obs.bed }}$ observed bed density $\mathrm{g} / \mathrm{cm}^{3}$.

Table 4. Main physical features of crude oil samples investigated

\begin{tabular}{|c|c|}
\hline Property & Value \\
\hline API & 26.5 \\
\hline Specific gravity, $15 / 4{ }^{\circ} \mathrm{C}$ & 0.898 \\
\hline Sulfur content, wt.\% & 2.75 \\
\hline $\begin{array}{l}\text { Specific gravity, (water at } \\
\left.60^{\circ} \mathrm{F}\right)\end{array}$ & 0.896 \\
\hline $\begin{array}{c}\text { Kinematic viscosity, }\left(\mathrm{mm}^{2} / \mathrm{s}\right), \\
15^{\circ} \mathrm{C}\end{array}$ & 46 \\
\hline Dynamic viscosity, c P, $15^{\circ} \mathrm{C}$ & 41 \\
\hline Vol. $\%$ residue ,b. p. $>210^{\circ} \mathrm{C}$ & $\mathbf{8 0}$, Sulfur content $3.7 \mathrm{wt} \%$ \\
\hline Vol.\%residue, b. p. $>290{ }^{\circ} \mathrm{C}$ & 66, Sulfur content $4.3 \mathrm{wt} \%$ \\
\hline Vol.\%residue, b. p.> $330^{\circ} \mathrm{C}$ & 54, Sulfur content $4.65 \mathrm{wt} \%$ \\
\hline
\end{tabular}




\subsection{Reactor System}

Reactor System applied was plug flow reactor with possible recycle, equipped with a fixed catalyst bed. The inside diameter of the reactor is $15 \mathrm{~mm}$ and the length is $230 \mathrm{~mm}$. The reactor is made from a $316 / 316 \mathrm{~L}$ stainless steel metal alloy designed to operate at pressures up to 100 atm. and temperatures up to $450^{\circ} \mathrm{C}$. Catalyst bed is loaded with catalyst particles of two sizes. The first size used is the pulverized particles with particle diameter $\left(D_{p}\right)$ ranging between $0.295 \mathrm{~mm}$ and $0.417 \mathrm{~mm}$ (35-mesh and 48- mesh) and the other size used is of the cylindrical extrudates with $1.58 \mathrm{mmin}$ diameter and $3.5 \mathrm{~mm}$ in length.

Since the fluid flow in Fixed bed reactors may involve inter-pellet transfer limitations depending on both axial and radiant dispersion of reactant mixtures. In order to assure the plug flow character of the reactor, Peclet $(\mathrm{Pe})$ number values for both profiles, the axial and radiant dispersions must have certain values depending on phases treated. Design and operation of fixed bed flow reactors with minimized axial dispersion, must push Peclet number towards higher values $\left(\mathrm{P}_{\mathrm{e}}=\mathrm{uL} / \mathrm{D}_{\text {eff }}\right)$, with $\mathrm{u}$ as the velocity of fluid flowing and $\mathrm{L}$ being the reactor depth and $\mathrm{D}_{\text {eff }}$ is the effective diffusivity coefficient. For this purpose a small reactor with Length to internal diameter $\left(D_{\text {in }}\right)$ ratio $\left(\mathrm{L} / \mathrm{D}_{\text {in }}\right)$ approaching 15 is used in this investigation. It is also desired to operate a reactor having some of the benefits of tubular plug flow reactor with the advantages of mixed flow reactors hydrodynamics, for this purpose a small fixed bed reactor with very high recycle ratio (R) which results in the modification of the performance equation of the fixed bed towards that of the mixed flow reactors.

All samples used are treated first with Hydrogen at $300^{\circ} \mathrm{C}$ and $50 \mathrm{~atm}$. and Hydrogen flow rate of $5700 \mathrm{ml} / \mathrm{h}$, at normal temperature and pressure (NTP). All samples are sulfide in situ with feedstocks at real operating conditions.

\subsection{Process Description}

Fresh feed is mixed with hydrogen, pumped and fed to the preheating unit E1 and then to the heater E2. The high pressure and high temperature mixture is fed to the reactor which is equipped with a fixed bed of $\mathrm{CoO}-\mathrm{MoO} / \gamma-\mathrm{Al}_{2} \mathrm{O}_{3}$ catalyst particles with recycling facility of the exit stream. The product on leaving the reactor is applied to preheat the fresh feed, then the products are cooled in E3 and their pressure is reduced and fed to the separation tank D1 at low pressure. The liquids are separated from the bottom and the gases from the top. Gases are purified by removing $\mathrm{H}_{2} \mathrm{~S}$ with alkali and the remaining Hydrogen is recycled and mixed with the makeup Hydrogen and fed to the inlet feed line with the fresh feed stocks. A process flow diagram is shown in Figure 1.

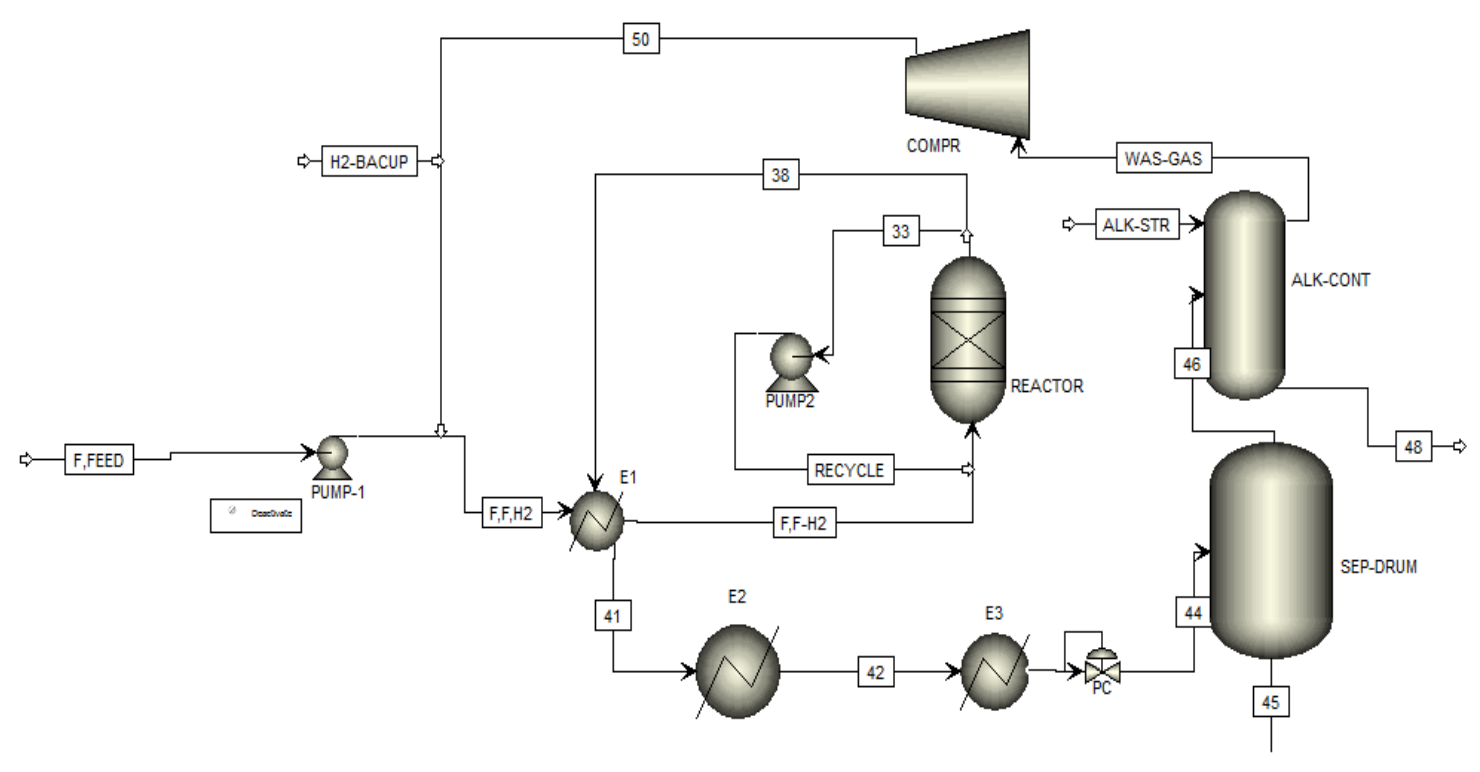

Figure 1. Process flow diagram of the Hydrodesulphurization unit 


\subsection{Mathematical Treatment of Experimental Results}

\section{Kinetic Model}

Initially a kinetic study is carried out to deduce a rate equation for the HDS reaction, based on a simplified form of Hougen-Watson kinetic model: $\mathrm{R}_{\mathrm{HDS}}=\mathrm{k}_{\mathrm{v}}{ }^{*} \mathrm{p}_{\mathrm{H} 2} *\left(\mathrm{C}_{\mathrm{S}}\right)^{\mathrm{n}} /$ $\left\{1+\mathrm{K}_{\mathrm{H} 2} * \mathrm{p}_{\mathrm{H} 2}\right\}$.

Determination of $\mathrm{n}, \mathrm{k}_{\mathrm{v}}$ and $\mathrm{K}_{\mathrm{H} 2}$ is based on conversion data on a plug flow reactor with a high recycle ratio, $\mathrm{R}$. The analysis is based on the performance equation of the plug flow reactor with large recycle ratio $\mathrm{R}$ ( $100 \%$ back mixing), $\tau=\mathrm{V}_{\mathrm{R}} / v_{\mathrm{t} 0}=\mathrm{C}_{\mathrm{S} 0} * \mathrm{X}_{\mathrm{f}} / \mathrm{R}_{\mathrm{HDS}}$, where $\tau$ is the space time min, $\mathrm{V}_{\mathrm{R}}$ is the catalyst bed volume $\mathrm{cm}^{3}, v_{\mathrm{t} 0}$ is the volumetric flow rate of the feed plus Hydrogen entering the reactor $\mathrm{cm}_{\text {mix. }}^{3} / \mathrm{h}$, [at reactor operating conditions], $\mathrm{C}_{\mathrm{S} 0}$ is the initial concentration of sulfur in the feed stocks g-mole $\mathrm{S} / \mathrm{cm}^{3}{ }_{\text {oil }}$, $\mathrm{X}_{\mathrm{f}}$ is the final chemical conversion of sulfur attained at steady state conditions and $\mathrm{R}_{\mathrm{HDS}}$ is the reaction rate of sulfur removal g-mol S/ $\mathrm{cm}^{3}$ cat. $\mathrm{s}$.

At steady state conditions values of the effluent sulfur content are measured at different space times. Sulfur concentration $\mathrm{C}_{\mathrm{S}}$ is evaluated from the following relation:

$$
\mathrm{C}_{\mathrm{S}}=\{\mathrm{S} \% \mathrm{wt} . / 3200\} * 1.007, \mathrm{~g}-\mathrm{mol} / \mathrm{cm}^{3}{ }_{\text {oil }} \text {. }
$$

Reaction rates are calculated applying the performance equation of a plug flow reactor with $\mathrm{R} \gg,(100 \%$ back mixing).

$\mathrm{R}_{\mathrm{HDS}}=\mathrm{C}_{\mathrm{S} 0} * \mathrm{X}_{\mathrm{f}} / \tau=\left\{\left(\mathrm{C}_{\mathrm{S} 0} * \mathrm{X}_{\mathrm{f}}\right)^{*} v_{\mathrm{t} 0 \mathrm{t}}\right\} /\left(\mathrm{V}_{\mathrm{R} .} * 3600\right)$, $\mathrm{g}-\mathrm{mol} / \mathrm{cm}^{3}$ cat.s

The order of the reaction and reaction rate constant are deduced from a linear regression analysis of the resulting data, where $\operatorname{Ln}\left(\mathrm{R}_{\mathrm{HDS}}\right)$ is plotted versus $\mathrm{Ln}\left(\mathrm{C}_{\mathrm{S}}\right)$ with an intercept equal to $\mathrm{Ln}(\mathrm{k})$ and a slope equal to the order of the reaction $(n)$.

\subsection{Operating Conditions}

Feedstocks tested are the atmospheric residues of Arabian Heavy Crude Oil; the main features are given in Table 5 .

The effect of temperature and pressure on the reaction rate is investigated in the range of 300 to $380^{\circ} \mathrm{C}$ and 30 to $80 \mathrm{~atm}$. respectively. Kinetic investigation experiments were carried under steady state operating conditions.

Table 5. Properties of Treated Heavy Oil Residuum

\begin{tabular}{|c|c|}
\hline property & value \\
\hline Boiling point,${ }^{\circ} \mathrm{C}$ & $>330^{\circ} \mathrm{C}$ \\
\hline API & 9.0 \\
\hline $\mathrm{S}, \%$ wt. & 4.65 \\
\hline $\mathrm{V}+\mathrm{Ni}, \mathrm{ppm}$ & 132 \\
\hline Carbon residue, $\% \mathrm{Wt}$. & 13.62 \\
\hline $\mathrm{Sp}$. gravity, $15 / 4{ }^{\circ} \mathrm{C}, \mathrm{g} / \mathrm{cm}^{3}$ & 1.007 \\
\hline Kinematic viscosity, $122^{\circ} \mathrm{F}, \mathrm{cSt}$ & 229 \\
\hline
\end{tabular}

\section{Results for CAT-1 Catalyst Samples:}

Pulverized particles $\overline{\mathrm{Dp}}=0.356 \mathrm{~mm}, \mathrm{P}=50 \mathrm{~atm}, \mathrm{C}_{\mathrm{S} 0}=14$. $63310^{-4} \mathrm{~g}-\mathrm{mol} \mathrm{S} / \mathrm{cm}^{3}{ }_{\text {oil }}, \mathrm{API}=9$. The experimental data obtained at $\mathrm{T}=300^{\circ} \mathrm{C}, 330^{\circ} \mathrm{C}, 350^{\circ} \mathrm{C}, 380^{\circ} \mathrm{C}$ and the resulting values of the reaction rates and conversions calculated at different LHSV is show in Tables 6, 7, 8 and 9 respectively.

Table 6. Data obtained at $\mathrm{T}=300^{\circ} \mathrm{C}$

\begin{tabular}{|c|c|c|c|c|c|c|c|}
\hline Run number & 1 & 2 & 3 & 4 & 5 & 6 & 7 \\
\hline $\mathrm{v}_{0 \mathrm{il}}, \mathrm{cm}^{3} \mathrm{oil} / \mathrm{h}$ & 20 & 10 & 25 & 15 & 35 & 45 & 55 \\
\hline $\begin{array}{c}\mathrm{v}_{\mathrm{H} 2}, \mathrm{~cm}_{\mathrm{H} 2}^{3} / \mathrm{h} . \\
\{\mathrm{NTP}\}\end{array}$ & 1297.00 & 813 & 1621.00 & 973.00 & 2270.0 & 2919.0 & 3569.5 \\
\hline $\mathrm{v}_{\text {tot }}, \mathrm{cm}^{3} \mathrm{mix} / \mathrm{h}$ & 74.45 & 44.13 & 93.06 & 55.85 & 130.31 & 167.54 & 204.77 \\
\hline $\begin{array}{c}\text { Sulfur content, } \\
\text { S,wt. } \%\end{array}$ & 2.85 & 2.43 & 3.02 & 2.62 & 3.21 & 3.43 & 3.67 \\
\hline $\begin{array}{c}\mathrm{C}_{\mathrm{Sf}}, \\
\mathrm{g}-\mathrm{mol} / \mathrm{cm}^{3} \text { oil, } * 10^{4}\end{array}$ & 8.9686 & 7.6469 & 9.504 & 8.2448 & 10.101 & 10.794 & 11.549 \\
\hline $\mathrm{X}_{\mathrm{f}} \%$ & 38.71 & 47.74 & 35.06 & 43.66 & 30.97 & 26.24 & 21.08 \\
\hline $\begin{array}{c}\mathrm{R}_{\mathrm{HDS}},{ }^{*} 10^{7}, \\
\text { g-mol/cm } / \mathrm{cm}^{3} \text { cat.s }\end{array}$ & 3.0827 & 2.25350 & 3.4900 & 2.6083 & 4.3168 & 4.7025 & 5.0018 \\
\hline
\end{tabular}

Table 7. Data obtained at $\mathrm{T}=330^{\circ} \mathrm{C}$

\begin{tabular}{|c|c|c|c|c|c|c|c|}
\hline Run number & 1 & 2 & 3 & 4 & 5 & 6 & 7 \\
\hline $\mathrm{v}_{0}, \mathrm{~cm}^{3}$ oil $/ \mathrm{h}$ & 20 & 10 & 25 & 15 & 35 & 45 & 55 \\
\hline$v_{\mathrm{H} 2}, \mathrm{~cm}_{\mathrm{H} 2}^{3} / \mathrm{h}\{\mathrm{NTP}\}$ & 1297.00 & 813 & 1621.00 & 973.00 & 2270.0 & 2919.0 & 3569.5 \\
\hline$v_{\mathrm{H} 2}, \mathrm{~cm}^{3} \mathrm{H}_{2} / \mathrm{h}$ & 57.29 & 35.91 & 71.61 & 42.98 & 100.28 & 128.95 & 157.69 \\
\hline $\mathrm{U}_{\mathrm{tot}}, \mathrm{cm}_{\text {mix }}^{3} / \mathrm{h}$ & 77.29 & 45.91 & 96.61 & 57.98 & 135.28 & 173.95 & 212.69 \\
\hline Sulfur content, S,wt.\% & 2.45 & 2.05 & 2.72 & 2.41 & 2.93 & 3.09 & 3.27 \\
\hline $\mathrm{C}_{\mathrm{Sf}}, \mathrm{g}-\mathrm{mol} / \mathrm{cm}^{3}$ oil, $* 10^{4}$ & 7.7098 & 6.4063 & 8.5600 & 7.0805 & 9.2203 & 9.7238 & 10.2003 \\
\hline $\mathrm{X}_{\mathrm{f}} \%$ & 0.4731 & 56.22 & 41.50 & 48.17 & 36.99 & 33.55 & 30.29 \\
\hline $\begin{array}{c}\mathrm{R}_{\mathrm{HDS}},{ }^{*} 10^{7}, \\
\text { g-mol/cm } \mathrm{cm}^{3} \text { cat.s }\end{array}$ & 3.9113 & 2.7609 & 4.2421 & 2.9875 & 5.3526 & 6.2426 & 6.8912 \\
\hline
\end{tabular}




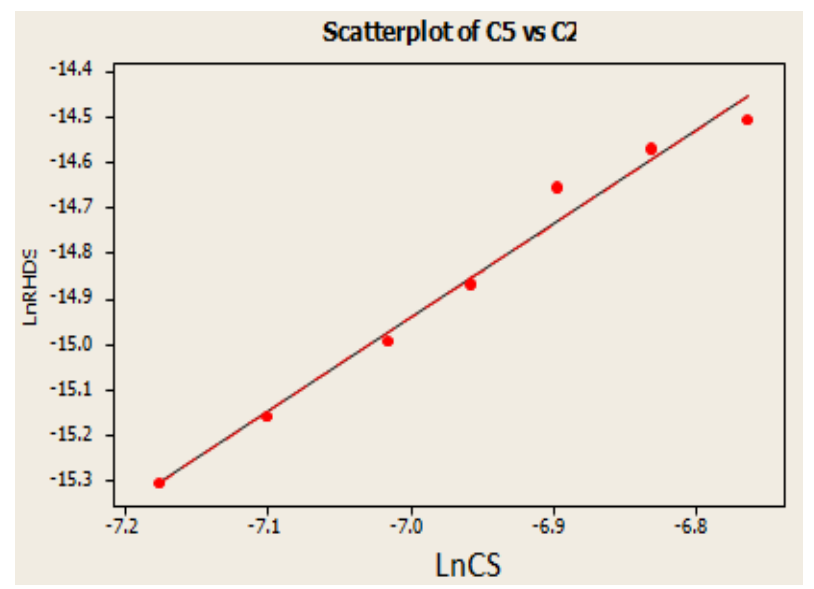

Figure 2. Regression Analysis: Ln $\mathrm{R}_{\mathrm{HDS}}$ versus Ln Cs for data obtained at $300^{\circ} \mathrm{C}$, Table 6 , CAT- 1

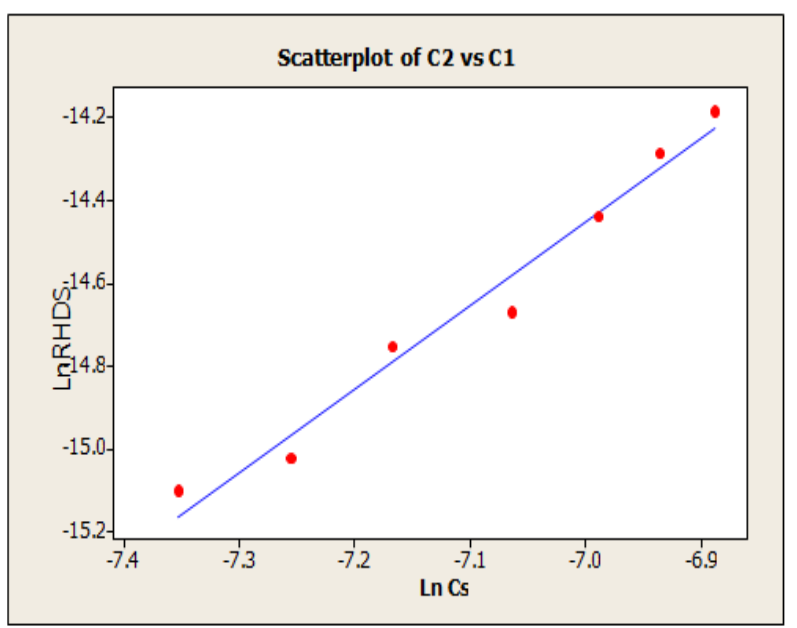

Figure 3. Regression Analysis: $\mathrm{Ln} \mathrm{R}_{\mathrm{HDS}}$ versus Ln Cs for data obtained at $330^{\circ} \mathrm{C}$, Table 7, CAT-1

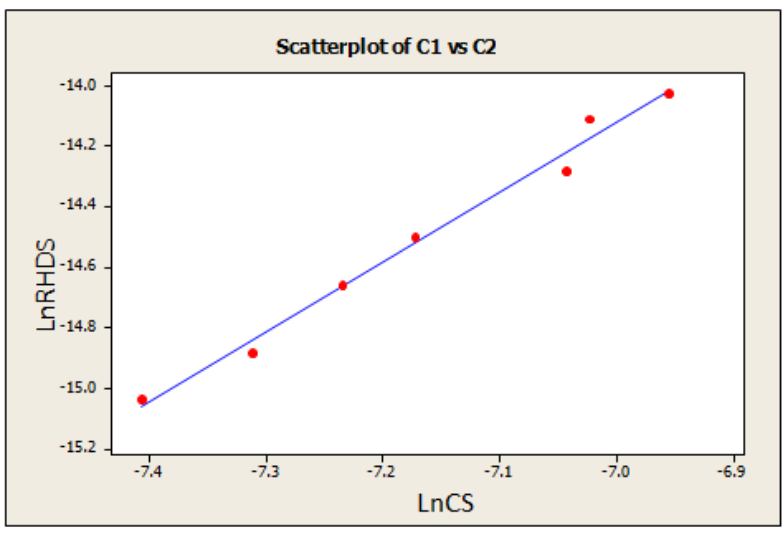

Figure 4. Regression Analysis: $\operatorname{Ln} \mathrm{R}_{\mathrm{HDS}}$ versus $\mathrm{Ln}$ Cs for data obtained at $350^{\circ} \mathrm{C}$, Table $8, \mathrm{CAT}-1$

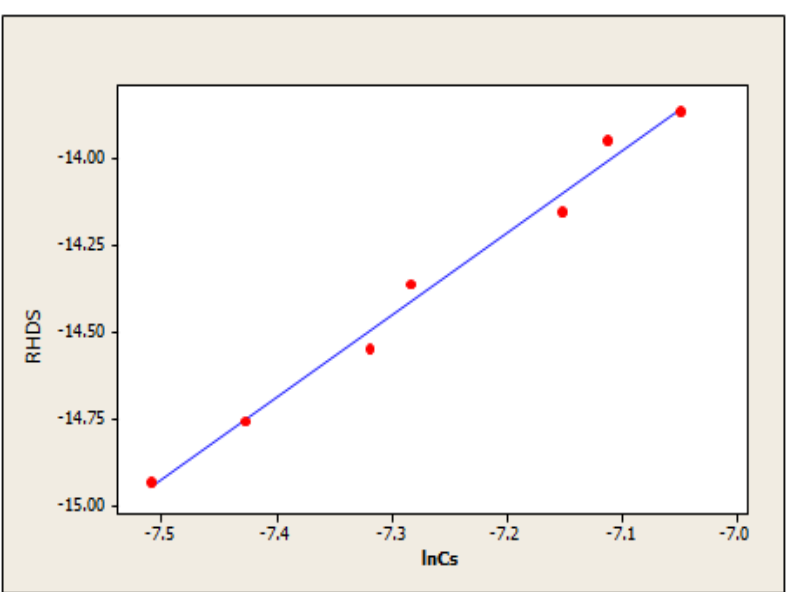

Figure 5. Regression Analysis: $\operatorname{Ln} \mathrm{R}_{\mathrm{HDS}}$ versus $\mathrm{Ln}$ Cs for data obtained at $380^{\circ} \mathrm{C}$, Table $9, \mathrm{CAT}-1$

The experimental points in Figure 2 are presented by the following equation:

$$
\text { Ln } \mathrm{R}_{\mathrm{HDS}}=-0.521+2.06 \mathrm{LnC}_{\mathrm{S}}
$$

With a slope $=2.06$ and an intercept $(\mathrm{Ln} \mathrm{k})=-0.521$. The product analysis showed that the Vol. \% of the product with boiling point From $\mathrm{C}_{5}$ to $210^{\circ} \mathrm{C}=1.5$ and that the Vol. \% of the product with boiling point $>210^{\circ} \mathrm{C}=96.5$, and the API degrees $=10.4$.

The experimental points in Figure 3 are presented by the following equation:

$$
\text { Ln } \mathrm{R}_{\mathrm{HDS}}=-0.31+2.02 \mathrm{Ln} \mathrm{CS}
$$

With a slope $=2.02$ and an intercept $=-0.31$. The product analysis showed that the Vol. \% of the product with boiling point From $\mathrm{C}_{5}$ to $210^{\circ} \mathrm{C}=2.8$ and that the Vol. \% of the product with boiling point $>210^{\circ} \mathrm{C}=94.2$, and the API degrees $=11.7$.

The experimental points in Figure 4 are presented by the following equation:

$$
\text { Ln } \mathrm{R}=2.08+2.31 \ln \mathrm{Cs} .
$$

Hence the slope $=2.31$ and the intercept $=2.08$, the Vol. \% of the product with boiling point from $\mathrm{C}_{5}$ to $210^{\circ} \mathrm{C}$ $=6.3$ and the Vol. \% of the product with boiling point $>210^{\circ} \mathrm{C}=87.2$, the API degrees $=13.2$

The experimental points in Figure 5 are presented by the following equation:

$$
\text { Ln } \mathrm{R}=2.80+2.36 \ln \mathrm{Cs} .
$$

The Vol. \% of the product with boiling point from $\mathrm{C}_{5}$ to $210^{\circ} \mathrm{C}=8.9$ while the Vol. $\%$ of the product with boiling point $>210^{\circ} \mathrm{C}=81.6$, degrees $\mathrm{API}=15.6$. 
Table 8. Data obtained at $\mathrm{T}=350^{\circ} \mathrm{C}$

\begin{tabular}{|c|c|c|c|c|c|c|c|}
\hline Run number & 1 & 2 & 3 & 4 & 5 & 6 & 7 \\
\hline$v_{0}, \mathrm{~cm}^{3}$ oil $/ \mathrm{h}$ & 20 & 10 & 25 & 15 & 35 & 45 & 55 \\
\hline $\begin{array}{c}v_{\mathrm{H} 2}, \mathrm{~cm}^{3}{ }^{3} 2 \\
\mathrm{~h}\{\mathrm{NTP}\}\end{array}$ & 1297.00 & 813 & 1621.00 & 973.00 & 2270.0 & 2919.0 & 3569.5 \\
\hline$v_{\mathrm{H} 2}, \mathrm{~cm}^{3} \mathrm{H}_{2} / \mathrm{h}$ & 59.2 & 37.10 & 74.0 & 44.40 & 103.6 & 133.20 & 162.9 \\
\hline$v_{\text {tot }}, \mathrm{cm}_{\text {mix }}^{3} / \mathrm{h}$ & 79.2 & 47.1 & 99.0 & 59 & 138.6 & 178.2 & 217.9 \\
\hline $\begin{array}{l}\text { Sulfur content, } \\
\text { S,wt. } \%\end{array}$ & 2.29 & 1.93 & 2.44 & 2.12 & 2.69 & 2.83 & 3.03 \\
\hline $\begin{array}{c}\mathrm{C}_{\mathrm{Sf}}, \\
\mathrm{g}-\mathrm{mol} / \mathrm{cm}^{3} \mathrm{oil} \\
* 10^{4}\end{array}$ & 7.2063 & 6.0735 & 7.6784 & 6.6714 & 8.4651 & 8.9057 & 9.5350 \\
\hline $\mathrm{X}_{\mathrm{f}} \%$ & 50.75 & 58.49 & 47.53 & 54.41 & 42.15 & 39.14 & 34.83 \\
\hline $\begin{array}{c}\mathrm{R}_{\mathrm{HDS}},{ }^{*} 10^{7}, \\
\text { g-mol/cm }{ }^{3} \text { cat.s }\end{array}$ & 4.29940645 & 2.946794 & 5.0332707 & 3.43382385 & 6.2489649 & 7.460635 & 8.118167 \\
\hline
\end{tabular}

Table 9. Data obtained at $\mathrm{T}=380^{\circ} \mathrm{C}$

\begin{tabular}{|c|c|c|c|c|c|c|c|}
\hline Run number & 1 & 2 & 3 & 4 & 5 & 6 & 7 \\
\hline$v_{0}, \mathrm{~cm}^{3}$ oil $/ \mathrm{min}$ & 20 & 10 & 25 & 15 & 35 & 45 & 55 \\
\hline$v_{\mathrm{H} 2, \mathrm{~cm}^{3} \mathrm{H} 2 / \mathrm{h}\{\mathrm{NTP}\}}$ & 1297.00 & 813 & 1621.00 & 973.00 & 2270.0 & 2919.0 & 3569.5 \\
\hline$v_{\mathrm{H} 2}, \mathrm{~cm}^{3} \mathrm{H}_{2} / \mathrm{h}$ & 62.00 & 38.90 & 77.47 & 46.55 & 108.60 & 139.64 & 170.76 \\
\hline $\mathrm{v}$ tot, $\mathrm{cm}^{3} \mathrm{mix} / \mathrm{h}$ & 82.00 & 48.90 & 102.00 & 61.55 & 1453.6 & 184.64 & 225.76 \\
\hline $\begin{array}{c}\text { Sulfur content, } \\
\text { S,wt.\% }\end{array}$ & 1.99 & 1.74 & 2.18 & 1.89 & 2.49 & 2.59 & 2.76 \\
\hline $\begin{array}{c}\mathrm{C}_{\mathrm{Sf}}, \mathrm{g}-\mathrm{mol} / \mathrm{cm}^{3} \text { oil, } \\
* 10^{4}\end{array}$ & 6.6262 & 5.4756 & 6.8602 & 5.9476 & 7.8357 & 8.1504 & 8.6854 \\
\hline $\mathrm{X}_{\mathrm{f}} \%$ & 54.72 & 62.58 & 53.12 & 59.35 & 46.45 & 44.30 & 39.42 \\
\hline $\begin{array}{c}\mathrm{R}_{\mathrm{HDS}}{ }^{*} 10^{7}, \\
\mathrm{~g}-\mathrm{mol} / \mathrm{cm}^{3} \mathrm{cat} . \mathrm{s}\end{array}$ & 4.799624 & 3.273344 & 5.795695 & 3.9075 & 7.13489 & 8.74937 & 9.51943 \\
\hline Ln R & -14.5496 & -14.9323 & -14.36098 & -14.75520 & -14.153098 & -13.9491 & -13.8648 \\
\hline LnCs & -7.31931 & -7.510039 & -7.28460 & -7.427352 & -7.15165 & -7.1123 & -7.0487 \\
\hline
\end{tabular}

These results showed that the average value of the reaction order is $2.188(\approx 2.2)$ and that the presence of molecular sieves MS13-X affected the selectivity of the reaction producing lighter materials by directing towards the hydrocracking reaction. The fraction of lighter products increased with increasing temperature. It was found out that the trend of the reaction to produce lighter products increased with increasing temperature. $\mathrm{C}_{1}-\mathrm{C}_{4}$ percentage in the products increased to $9.5 \% \mathrm{vol}$ at $380^{\circ} \mathrm{C}$. The API grades showed a trend to increase with temperature which is found to be 15.6 applying a temperature of $380^{\circ} \mathrm{C}$.

The frequency factor and the activation energy are deduced by plotting Ln $\mathrm{k}$ vs. 1/T as shown in Table 10.

Table 10. Temperature dependency of reaction rate constant $\mathrm{Ln}(\mathrm{k})$ versus $(1 / \mathrm{T})$ for CAT-1.

\begin{tabular}{|c|c|c|c|c|}
\hline $\mathrm{T}, \mathrm{K}$ & 573 & 603 & 623 & 653 \\
\hline $1 / \mathrm{T} * 10^{3}, \mathrm{~K}^{-1}$ & 1.745 & 1.658 & 1.605 & 1.53 \\
\hline Ln k & -0.521 & -0.31 & 2.08 & 2.8 \\
\hline
\end{tabular}

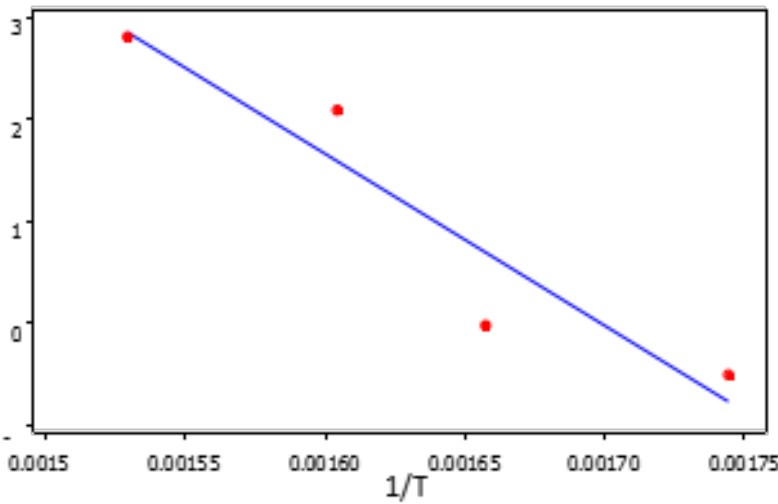

Figure 6. Arrhenius plot Lnk vs $1 / \mathrm{T}$ for CAT-1

The regression equation is:

$$
\text { Lnk }=28.9-170581 / \mathrm{T}
$$

Hence $\mathrm{Ln} \mathrm{k}_{0}=28.9$, and $-\mathrm{E} / \mathrm{R}=-17058$ 
Arrhenius plots relating the reaction rate constant $\mathrm{k}$ and the reciprocal of the applied temperature 1/T, Figure 6, showed that the Arrhenius expression for the reaction rate constant is:

$$
\mathrm{k}=3.557 * 10^{12} \exp (-17058 / \mathrm{T}) .
$$

Hence $\mathrm{E} / \mathrm{R}=17058 \mathrm{~K}^{-1}$ and the frequency factor $\mathrm{k}_{0}$ $=3.557 * 10^{12}$.

\section{Effect of Hydrogen Pressure}

The effect of hydrogen pressure on the hydro-desulfurization reaction is studied at a temperature of $350^{\circ} \mathrm{C}, \overline{\mathrm{Dp}}=0.356 \mathrm{~mm}$ with feed sulfur concentration $\left(\mathrm{C}_{\mathrm{Sf}}\right)$ of $14.633^{*} 10^{-4} \mathrm{~g}-\mathrm{mol} \mathrm{S} / \mathrm{cm}^{3}{ }_{\text {oil }}$, LHSV $2.084 \mathrm{~h}^{-1}$ in the region of hydrogen pressures between 30 and $80 \mathrm{~atm}$.Reaction rate constants $\mathrm{k}$ are calculated for reaction orders $\mathrm{n}=2$ 2.2. I.e. $\mathrm{k}={ }_{\mathrm{HDS}} * 10^{-7} / \mathrm{C}_{\mathrm{Sf}}^{2.2}$. The experimental results are shown in Table 11 .

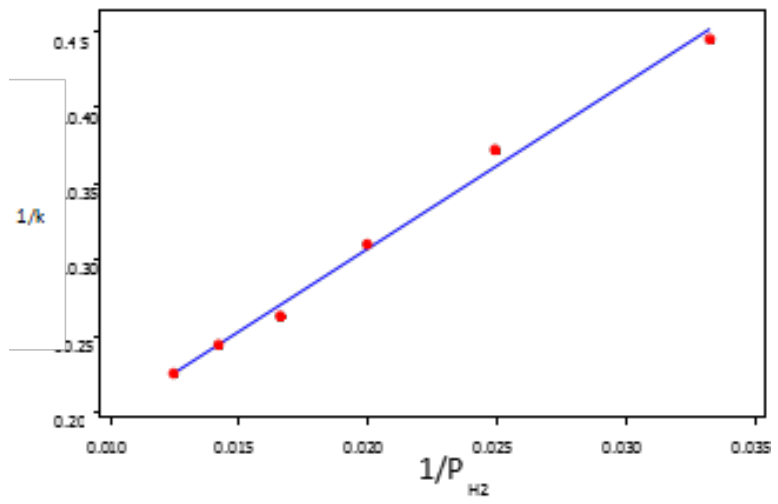

Figure 7. Scatterplot of $1 / \mathrm{k}$ vs $1 / \mathrm{P}_{\mathrm{H} 2}$ for CAT-1
The inhibition effects of Hydrogen shown in Table-11 are depicted in Figure 7.

Based on the following relation:

$$
\mathrm{k}=\mathrm{k}_{\mathrm{v}} * \mathrm{P}_{\mathrm{H} 2} /\left(1+\mathrm{K}_{\mathrm{H} 2} * \mathrm{P}_{\mathrm{H} 2}\right)
$$

where $\mathrm{k}$ is the observed reaction rate constant and $\mathrm{K}_{\mathrm{H} 2}$ is the hydrogen adsorption equilibrium coefficient while $\mathrm{k}_{v}$ is the intrinsic reaction rate constant.

Inversing both sides of "(7)":

$$
1 / \mathrm{k}=1 /\left(\mathrm{k}_{\mathrm{v}} * \mathrm{P}_{\mathrm{H} 2}\right)+\mathrm{K}_{\mathrm{H} 2} \cdot \mathrm{P}_{\mathrm{H} 2} /\left(\mathrm{k}_{\mathrm{v}} \cdot \mathrm{P}_{\mathrm{H} 2}\right) \text {. }
$$

The intrinsic reaction rate constant and the inhibition effects of Hydrogen (neglecting the low mole fraction of $\mathrm{H}_{2} \mathrm{~S}$ ) were deduced.

The plot of the reciprocal of reaction rate constant $\mathrm{k}$ and the reciprocal of the Hydrogen pressure $\left(\mathrm{P}_{\mathrm{H} 2}\right)$ presented in Figure 7 yielded the following regression equation:

$$
1 / \mathrm{k}=0.0875+10.9 * 1 / \mathrm{P}_{\mathrm{H} 2} .
$$

The slope of the line is 10.9 , thus the intrinsic reaction rate constant $\mathrm{k}_{\mathrm{v}}$ is found 0.091743 and from the intercept $=$ 0.00875 , the Hydrogen adsorption equilibrium coefficient $\mathrm{K}_{\mathrm{H} 2}$ is found to be $0.008028 \mathrm{~atm}^{-1}$, showing the Inhibition effects of Hydrogen.

The intrinsic reaction rate constant calculated from Arrhenius equation " $(6)$ " is:

$$
\mathrm{k}=3.557 * 10^{12} \exp (-17058 / \mathrm{T}) \text {. }
$$

Which is equal to $\mathrm{k}_{\mathrm{v}} * \mathrm{P}_{\mathrm{H} 2} /\left(1+\mathrm{K}_{\mathrm{H} 2} * \mathrm{P}_{\mathrm{H} 2}\right)$. Hence

$\mathrm{kv}=\left\{3.557 * 10^{12} * \exp (-17058 / \mathrm{T}) *(1+0.008028 * 50)\right\} / 50$

\begin{tabular}{|c|c|c|c|c|c|c|}
\hline Sulfur content, S,wt.\% & 2.62 & 2.48 & 2.35 & 2.23 & 2.17 & 2.12 \\
\hline $\mathrm{C}_{\mathrm{Sf}}, \mathrm{g}-\mathrm{mol} / \mathrm{cm}^{3}$ oil, $* 10^{4}$ & 8.244813 & 7.8225 & 7.3951 & 7.01753 & 6.82872 & 6.6761375 \\
\hline $\mathrm{Xf} \%$ & 43.66 & 46.54 & 49.46 & 52.04 & 53.33 & 54.41 \\
\hline LHSV, $\mathrm{h}^{-1}$ & 2.084 & 2.084 & 2.084 & 2.084 & 2.084 & 2.084 \\
\hline $\mathrm{R}_{\mathrm{HDS}} * 10^{7}, \mathrm{~g}-\mathrm{mol} \mathrm{S} / \mathrm{cm}_{\text {cat }}^{3} \mathrm{~s}$ & 3.6983866 & 3.94235 & 4.189773 & 4.408247 & 4.51752 & 4.60901 \\
\hline $\mathrm{k}$ & 2.2512024 & 2.69398 & 3.2397 & 3.82525 & 4.16249 & 4.4703 \\
\hline${ }_{\mathrm{H} 2}^{\mathrm{P}}, \mathrm{atm}$ & 30 & 40 & 50 & 60 & 70 & 80 \\
\hline $1 / \mathrm{k}$ & 0.444207 & 0.3712 & 0.30867 & 0.2614204 & 0.24302 & 0.223700 \\
\hline $1 / \mathrm{P}_{\mathrm{H} 2}, \mathrm{~atm}^{-1} * 10^{3}$ & 33 & 25 & 20 & 16.67 & 14.28 & 12.5 \\
\hline
\end{tabular}

$$
\text { Thus } \mathrm{kv}=9.9696^{*} 10^{10} \exp (-17058 / \mathrm{T})
$$

Table 11. Data obtained at $\mathrm{T}=300^{\circ} \mathrm{C}, \mathrm{CAT}-1, \overline{L p}_{0}$

Table 12. Data obtained at $\mathrm{T}=300^{\circ} \mathrm{C}, \mathrm{CAT}-1, \overline{L p}_{1}$

\begin{tabular}{|c|c|c|c|c|c|c|c|}
\hline Run number & 1 & 2 & 3 & 4 & 5 & 6 & 7 \\
\hline$v_{0 i 1}, \mathrm{~cm}^{3}$ oil $/ \mathrm{h}$ & 20 & 10 & 25 & 15 & 35 & 45 & 55 \\
\hline$v_{\mathrm{H} 2,} \mathrm{~cm}^{3} \mathrm{H}_{2} / \mathrm{h} .\{\mathrm{NTP}\}$ & 1297.00 & 813 & 1621.00 & 973.00 & 2270.0 & 2919.0 & 3569.5 \\
\hline$v_{\text {tot }}, \mathrm{cm}^{3} \mathrm{mix} / \mathrm{h}$ & 78.53 & 44.13 & 93.06 & 55.85 & $\begin{array}{c}130.31 \\
117.8\end{array}$ & 167.54 & $\begin{array}{c}204.77 \\
233.77\end{array}$ \\
\hline Sulfur content, S,wt.\% & 3.83 & 3.63 & 3.90 & 3.72 & 3.98 & 4.08 & 4.19 \\
\hline $\begin{array}{c}\mathrm{C}_{\mathrm{Sf}}, \\
\mathrm{g}-\mathrm{mol} / \mathrm{cm}^{3} \text { oil, } * 10^{3}\end{array}$ & 1.20539 & 1.142302 & 1.22728 & 1.17064 & 1.252505 & 1.283904 & 1.31541 \\
\hline $\mathrm{X}_{\mathrm{f}} \%$ & 17.63 & 21.94 & 16.13 & 20.00 & 14.41 & 12.26 & 09.89 \\
\hline $\begin{array}{c}\mathrm{R}_{\mathrm{HD}}{ }^{*} 10^{7} \\
\mathrm{~g}-\mathrm{mol} / \mathrm{cm}^{3} \text { cat.s }\end{array}$ & 1.480671 & 1.03562 & 1.6056 & 1.19481 & 1.8173795 & 2.197226 & 2.44732515 \\
\hline
\end{tabular}




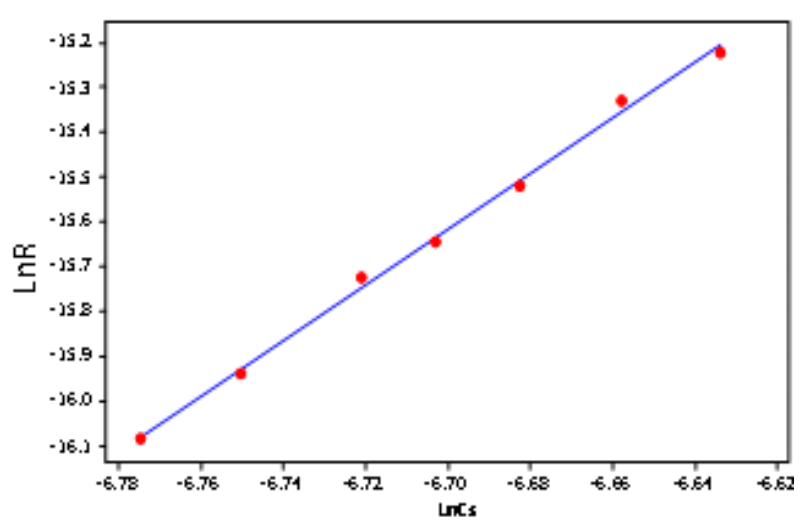

Figure 8. Regression Analysis: Ln (RHDS) vs. Ln (Cs), for data obtained at $300^{\circ} \mathrm{C}, \mathrm{CAT}-1, \overline{L p}_{1}=0.326 \mathrm{~mm}$

Hence at $350^{\circ} \mathrm{C}$ the value of $\mathrm{k}_{v}$ is 0.1176 which is slightly higher than the abovementioned calculated value for $\mathrm{k}_{v}=0.091743$. One is to consider an average value for $\mathrm{k}_{\mathrm{v}}$ at $350^{\circ} \mathrm{C}$ and $50 \mathrm{~atm}, \overline{k v}=0.1046715$ or

$$
\mathrm{k}_{v}=8.1469^{*} 10^{10} \exp (-17058 / \mathrm{T}) \ldots
$$

The second size of catalyst particles applied is the cylindrical extrudates with an average particle diameter $\overline{\mathrm{Dp}}=1.58 \mathrm{~mm}$, and average length $=3.5 \mathrm{~mm}, \overline{L p}_{1}=0.0327$ cm. $\mathrm{P}=50$ atm, $\mathrm{C}_{\mathrm{So}}=14.63310^{-4} \mathrm{~g}-\mathrm{mol} \mathrm{S} / \mathrm{cm}^{3}{ }_{\text {oil }}$, degrees $\mathrm{API}=9$

The experimental data was performed at $\mathrm{T}=300^{\circ} \mathrm{C}$, and the resulting values of the reaction rates and conversions calculated at different LHSV for CAT-1 with $\overline{L p}_{1}$ is shown in Table 12. These results are to be compared with those obtained by applying the pulverized particles.

The experimental data shown in Table 12 presented in Figure 8 is represented by the following equation:

$$
\operatorname{Ln} \mathrm{R}_{\mathrm{HDS}}=21.7+5.56 \mathrm{Ln} \mathrm{C}_{\mathrm{S}} \text {. }
$$

The product analysis showed that the Vol. \% of the product with boiling points From $\mathrm{C}_{5}$ to $210^{\circ} \mathrm{C}=1.0$ the Vol. $\%$ of the product with boiling point $>210^{\circ} \mathrm{C}=98.2$, and the API degrees $=10.2$.

\section{Effect of Particle Size}

The two particle sizes used, the pulverized with $\overline{\mathrm{Dp}}=$ $0.356 \mathrm{~mm}$, with a characteristic length $\overline{L p}_{0}=0.059 \mathrm{~mm}$ and the cylindrical extrudates with a characteristic length $\overline{L p}_{1}=$ $0.326 \mathrm{~mm}$.

Effectiveness factor $\eta$ and effective diffusivity ( $\left.D_{\text {eff }}\right)$ determination is based on observed reaction rates determined for fresh catalyst samples with relative activity $(\varepsilon)=1$.

For $\mathrm{k}_{\text {observed }}=\mathrm{k}_{\mathrm{v}} \cdot{ }^{\varepsilon} \cdot \eta$. The value of $\mathrm{k}_{\mathrm{v}}$ given in (11). For ${ }^{\varepsilon}$ $=1$, the effectiveness factor $\eta$ is estimated as a function of the Thiele modulus $\Phi$.

$$
\left.\Phi=\overline{L p} *\left\{(\mathrm{n}+1) * \mathrm{k}^{*}{ }^{*} \mathrm{C}_{\mathrm{s}}^{\mathrm{n}-1}\right) / 2 \mathrm{D}_{\mathrm{eff}}\right\}^{0.5}
$$

$\mathrm{n}$ is the reaction order, the observed reaction rate constant $\mathrm{k}=k_{v} * P_{H_{2}} /\left(1+K_{H 2} * P_{H 2}\right)$ and $\mathrm{D}_{\text {eff }}$ is the effective diffusivity of sulfur compounds $\left(\mathrm{cm}^{2} / \mathrm{s}\right)$.

The $\left.\mathrm{R}_{(\mathrm{HDS}}\right)_{0}$ and $\mathrm{R}_{(\mathrm{HDS}) 1}$ observed for catalyst particles with $\overline{L p}_{0}$ and $\overline{L p}_{1}$ and the relation, $\eta=\mathrm{f}(\Phi)$ presented in Figure 9 , are used in the effectiveness factor and $D_{\text {eff }}$ calculations.

Hence the following relations are applied:

$$
\begin{aligned}
& \left.\mathrm{R}_{(\mathrm{HDS}}\right)_{0} / \mathrm{R}_{(\mathrm{HDS}) 1}=\eta_{0} / \eta_{1} \\
& \text { And } \overline{L p_{0}} / \overline{L p}_{1}=\Phi_{0} / \Phi_{1}
\end{aligned}
$$

For R $\left({ }_{\text {HDS }}\right)_{0}=3.0827 * 10^{-7} \mathrm{~g}-\mathrm{mol} / \mathrm{cm}^{3}$ cat.s, (see Table 16) and $\mathrm{R}_{(\mathrm{HDS}) 1}=1.480671 * 10^{-7} \mathrm{~g}-\mathrm{mol} / \mathrm{cm}^{3}$ cat.s, (see Table12). Hence $\left.\mathrm{R}_{\text {(HDS }}\right)_{0} / \mathrm{R}_{\text {(HDS) } 1}=3.0827 / 1.480671=2.08196=$ $\eta_{0} / \eta_{1}$. Initially $\eta_{0}$ is assumed equal to 1 , thus the $\eta_{1}$ is found equal to 0.4803 , for $\eta_{0=1}$. Thus from Fig. $9, \Phi_{0}$ is equal 0.27 and for $\eta_{1}=0.4803$, the corresponding $\Phi_{1}$ as determined from the relation $\eta=\mathrm{f}(\Phi)$ is equal to 1.8 . Applying "(13)" and "(14)", the ratio $\overline{L p}_{0} / \overline{L p}_{1}=0.059 / 0.326=0.181$, which is not in good agreement with the calculated value of $\Phi_{0} / \Phi_{1}$ which is equal to $0.26 / 1.7=0.153$.

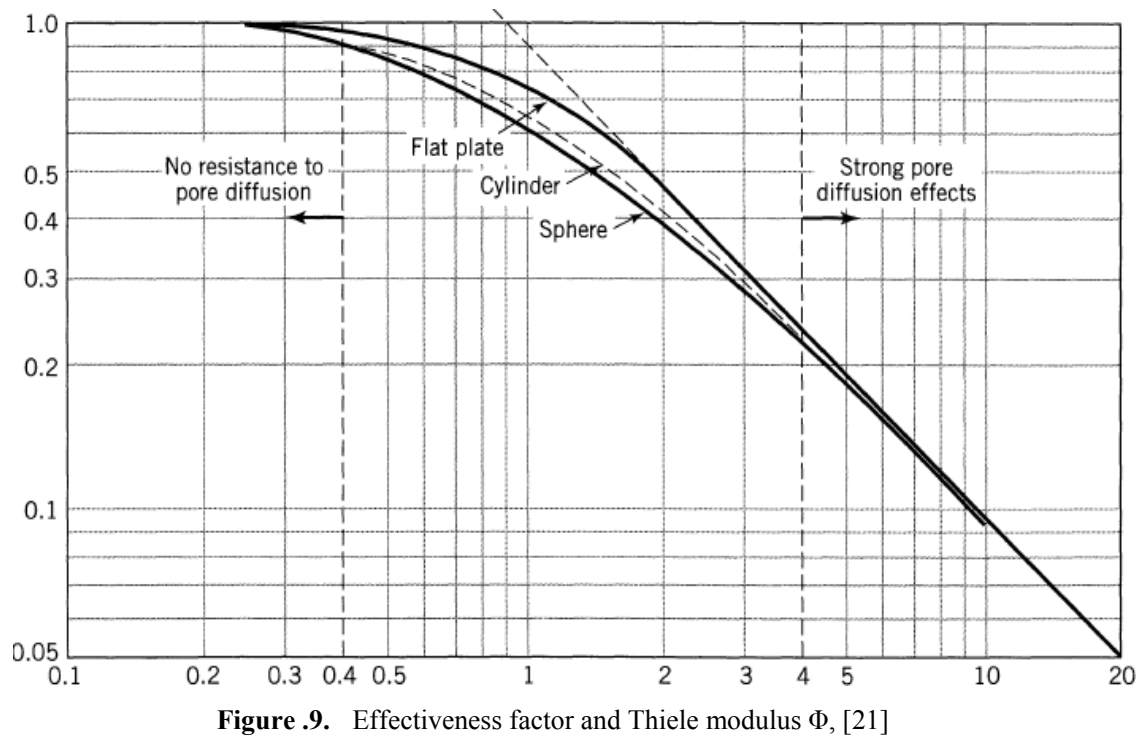


Trying another value of $\eta_{0}=0.96$, from equation (13), $\eta_{1}$ $=0.476$, thus applying fig. $7, \Phi_{0}$ is equal to 0.31 and $\Phi_{1}=$ 1.85 , by repeating these trials, we finally found that $\eta_{0}=$ 0.94 with $\Phi_{0}=0.343$ and $\eta_{1}=0.4515$ with resulted in $\Phi_{1}=$ 1.847. These final values justify" (13)" and" (14)".

Applying “(12)" for $\Phi_{0}$ :

$\left.\Phi_{0}=\overline{L p}_{0} *\left\{(\mathrm{n}+1) * \mathrm{k}^{*} * \mathrm{C}_{\mathrm{s}}^{\mathrm{n}-1}\right) / 2 \mathrm{D}_{\text {eff }}\right\}{ }^{0.5}$, substituting $\Phi_{0}=$ 0.343 and $\overline{L p}_{0}=0.059$, with $\mathrm{C}_{\mathrm{s}}=8.244813^{*} 10^{-4} \mathrm{~g}-\mathrm{mol} / \mathrm{cm}^{3} \mathrm{oil}$, and $\mathrm{n}=2.2$, the value of $\mathrm{k}$ is determined from ${ }^{\mathrm{R}}{ }_{\mathrm{HDS}} / \mathrm{C}_{\mathrm{s}}^{\mathrm{n}}=$ $\left[\left\{4.29940645 * 10^{-7} /\left(7.2063 * 10^{-4}\right\}^{2.2}\right]\right.$

$=3.519179,\left(\mathrm{~cm}_{\text {oil }}^{3}\right){ }^{2.2} * \mathrm{~g}-\mathrm{mol}^{-1.2} *\left(\mathrm{~cm}_{\text {cat }}^{3}\right)^{-1} 1^{*} \mathrm{~S}^{-1} * \mathrm{~atm}^{-1}$, (see Table 8).

Hence $\left(\mathrm{D}_{\text {eff }}\right)_{0}=2.824 * 10^{-7} \mathrm{~cm}^{2} / \mathrm{s}$ for $\overline{L p} \overline{0}_{0}=0.059$ $\mathrm{mm}=0.0059 \mathrm{~cm}$.

For $\overline{L p}_{1}=0.0326 \mathrm{~cm}, \quad \Phi_{1}=1.847, \quad \mathrm{C}_{\mathrm{s}=1.20539 * 10^{-3}}$ $\mathrm{g}-\mathrm{mol} / \mathrm{cm}^{3}$ oil, for $\mathrm{n}=2.2, \mathrm{k}={ }_{\mathrm{HDS}} / \mathrm{C}_{\mathrm{s}}^{\mathrm{n}}=1.480671 * 10^{-7} /$ $\left(1.20539 * 10^{-3}\right)^{2,2}=0.3908321$.

Thus $\mathrm{k}=0.39021$

Hence $\left(D_{\text {eff }}\right)_{1}=6.123 * 10^{-8} \mathrm{~cm}^{2} / \mathrm{s}$.

\section{Catalyst Activity and Performance}

Pulverized particles $\overline{L p_{0}}=0.356 \mathrm{~mm}$, were used at $\mathrm{P}=50$ atm, $\mathrm{T}=350^{\circ} \mathrm{C}, \mathrm{C}_{\mathrm{S} 0}=14.633 * 10^{-4} \mathrm{~g}-\mathrm{mol} \mathrm{S} / \mathrm{cm}^{3}{ }_{\text {oil }}, \mathrm{API}=9$, LHSV $=2.6 \mathrm{~h}^{-1}$.

Catalyst activity tests were carried on CAT-1 samples for periods up to $450 \mathrm{hrs}$. Of operation and catalyst activity is measured for the same catalyst particles by measuring the attained conversion versus catalyst age. The experimental results are shown in Table 13 and the graphical presentation is shown in Figure 10.
Table 13. Chemical conversion attained vs. Catalyst age, $\mathrm{ML}_{\text {oil }} / \mathrm{cm}^{3}$ cat

\begin{tabular}{|c|c|c|c|c|}
\hline $\begin{array}{c}\text { Catalyst } \\
\text { age } \mathrm{ML}_{\text {oil }} \\
\text { / }^{3} \text { cat. } \\
(10 \text { hours } \\
\text { daily })\end{array}$ & $\begin{array}{c}\text { Working } \\
\text { time, days }\end{array}$ & $\begin{array}{c}\text { Sulfur } \\
\text { content, } \mathrm{S} \\
\text { wt.\% }\end{array}$ & $\mathrm{X}_{\mathrm{f}} \%$ & $\begin{array}{c}\text { Relative } \\
\text { activity } \\
\mathrm{X} / \mathrm{X}_{0}\end{array}$ \\
\hline 6.6 & 1 & 2.35 & 49.46 & 1 \\
\hline 65.8 & 10 & 2.3 & 50.54 & 1.022 \\
\hline 98.7 & 15 & 2.34 & 49.68 & 1.004 \\
\hline 131.6 & 20 & 2.37 & 49.03 & 0.991 \\
\hline 164.5 & 25 & 2.45 & 47.31 & 0.957 \\
\hline 197.3 & 30 & 2.52 & 45.81 & 0.926 \\
\hline 230.2 & 35 & 2.55 & 45.23 & 0.914 \\
\hline 263.2 & 40 & 2.6 & 44.04 & 0.89 \\
\hline 296.1 & 45 & 2.8 & 39.78 & 0.804 \\
\hline
\end{tabular}

The results show that the activity is slightly increased during the first period of 100 hours of operation which may be attributed to an increase in the extent of sulfidation of the oxidic precursors. Then it remains constant for another period of about 100 hours. After these two hundred hours the activity decreases progressively with increasing time of operation and the volume of oil being treated, as shown in Figure 10 . The successive drop in relative activity after the first 300 hours may be caused by carbon deposition blocking partially some of the small pores and later by the deposition of metals blocking permanently some classes of pores having intermediate sizes of pore diameters. The total loss in catalyst activity after 450 hours of operation is approximately $20 \%$.

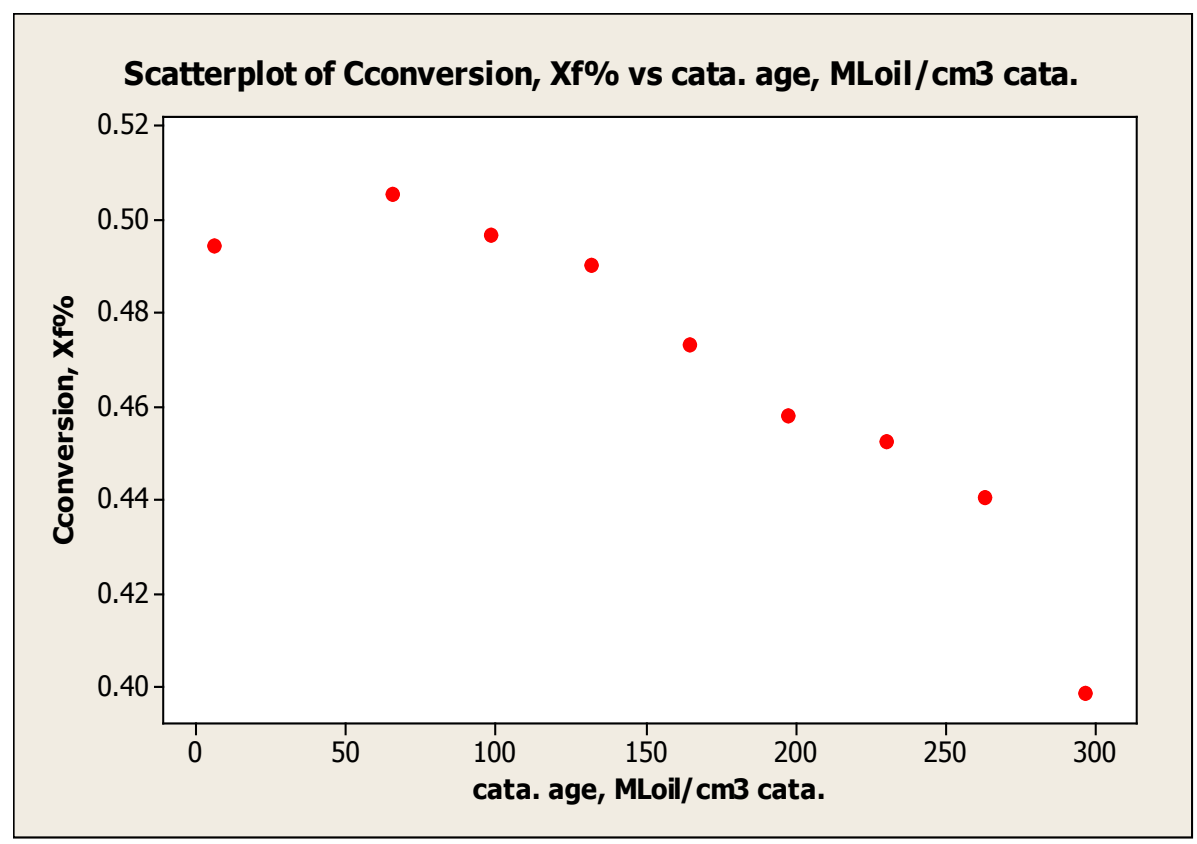

Figure. 10. Catalyst relative activity expressed as chemical conversion of sulfur compounds vs. catalyst operating time, $\mathrm{ML}$ oil $/ \mathrm{cm}^{3}$ catalyst approximately $20 \%$ 
It must be emphasized that Zeolites affect the $\mathrm{Co}-\mathrm{Mo} / \gamma$ Alumina catalysts activity during heavy oil hydro-treatment processes. The high surface area moderately acidic meso- and macro-porous structure of the $\gamma$ - Alumina support and the stable $\mathrm{X}$ zeolite. The micro-structure and the composition of the zeolite crystals formed in the bulk of the Alumina, lead to that we are to have two main phases found homogeneously distributed in the porous structure of the support. Co-Mo sulfide supported with $\gamma$ - Alumina catalysts applied for the Hydro treatment heavy oil fractions. The combination of the stable zeolite and alumina is able to provide catalysts with two types of pores small ones and moderately larger pores (bi-modal type of pores), which may contribute to a fruitful combination of Hydrodesulphurization (HDS), Hydrodemetallization (HDM) and the selective cracking of the very large Hydro carbon molecules called the Asphaltenes with heteroatoms over the acidic catalysts.

\section{For CAT-2 Catalyst Samples}

Pulverized catalyst particles with $\overline{\mathrm{Dp}}=0.356 \mathrm{~mm}$, of CAT-2 were subjected to the same conditions as applied for CAT- $1, \mathrm{P}=50 \mathrm{~atm}, \mathrm{~T}=350^{\circ} \mathrm{C}, \mathrm{C}_{\mathrm{S} 0}=14.63310^{-4} \mathrm{~g}-\mathrm{mol}$ $\mathrm{S} / \mathrm{cm}^{3}{ }_{\text {oil }}, \mathrm{API}=9$.

The experimental data obtained at $\mathrm{T}=350^{\circ} \mathrm{C}, 380^{\circ} \mathrm{C}$ and the resulting values of the reaction rate and conversion calculated at different LHSV are shown in Tables 14 and 15.

Table 14. Data obtained at $\mathrm{T}=350^{\circ} \mathrm{C}$

\begin{tabular}{|c|c|c|c|c|c|c|c|}
\hline Run number & 1 & 2 & 3 & 4 & 5 & 6 & 7 \\
\hline v0, $\mathrm{cm}^{3}$ oil $/ \mathrm{h}$ & 20 & 10 & 25 & 15 & 35 & 45 & 55 \\
\hline$v_{\mathrm{H} 2}, \mathrm{~cm}^{3} \mathrm{H}_{2} / \mathrm{h}$ & 60 & 36.97 & 73.48 & 45.19 & 104.42 & 139.699 & 164.76 \\
\hline vtot, $\mathrm{cm}^{3} \mathrm{mix} / \mathrm{h}$ & 80 & 46.97 & 98.48 & 60.19 & 139.42 & 174.699 & 219.76 \\
\hline S wt.\% & 2.33 & 1.99 & 2.51 & 2.13 & 2.73 & 2.85 & 3.06 \\
\hline $\begin{array}{c}\text { CSf, g-mol/cm }{ }^{3} \text { oil, } \\
* 104\end{array}$ & 7.3322 & 6.2623 & 7.8987 & 6.7029 & 8.5910 & 8.9686 & 9.6294 \\
\hline $\mathrm{Xf} \%$ & 49.89 & 57.20 & 46.02 & 54.19 & 41.29 & 38.71 & 34.84 \\
\hline$\tau$ & 0.476 & 0.809 & 0.386 & 0.631 & 0.273 & 0.217 & 0.173 \\
\hline $\begin{array}{l}\text { RHDS,*107, } \\
\text { g-mol/cmcat.s }\end{array}$ & 4.26027 & 2.8739 & 4.8087 & 3.49075 & 5.78979 & 7.2509 & 8.1858 \\
\hline
\end{tabular}

Table 15. Data obtained at $\mathrm{T}=380^{\circ} \mathrm{C}$

\begin{tabular}{|c|c|c|c|c|c|c|c|}
\hline Run number & 1 & 2 & 3 & 4 & 5 & 6 & 7 \\
\hline v0, $\mathrm{cm}^{3}$ oil $/ \mathrm{h}$ & 20 & 10 & 25 & 15 & 35 & 45 & 55 \\
\hline$v_{\mathrm{H} 2}, \mathrm{~cm}^{3} \mathrm{H}_{2} / \mathrm{h}$ & 62.0 & 39.0 & 75.3 & 43.9 & 106.2 & 131.8 & 162.6 \\
\hline vtot, $\mathrm{cm}^{3} \mathrm{mix} / \mathrm{h}$ & 82.0 & 49.0 & 100.3 & 58.9 & 141.2 & 176.8 & 217.6 \\
\hline $\begin{array}{c}\text { Sulfur content, } \\
\text { S,wt.\% }\end{array}$ & 2.04 & 1.77 & 2.23 & 1.94 & 2.54 & 2.63 & 2.81 \\
\hline $\begin{array}{c}\mathrm{CSf}, \mathrm{g}-\mathrm{mol} / \mathrm{cm}^{3} \text { oil, } \\
* 104\end{array}$ & 6.419625 & 5.56996875 & 7.01753 & 6.1049375 & 7.993063 & 8.276281 & 8.842719 \\
\hline $\mathrm{Xf} \%$ & 56.13 & 61.94 & 52.04 & 58.28 & 45.38 & 43.44 & 39.57 \\
\hline$\tau$ & 0.463 & 0.776 & 0.379 & 0.645 & 0.269 & 0.215 & 0.175 \\
\hline $\begin{array}{c}\text { RHDS, } * 107, \\
\text { g-mol/cm } 3 \text { cat.s }\end{array}$ & 4.9277 & 3.24649 & 5.5959878 & 3.6727 & 6.85714 & 8.2126 & 9.19092 \\
\hline
\end{tabular}




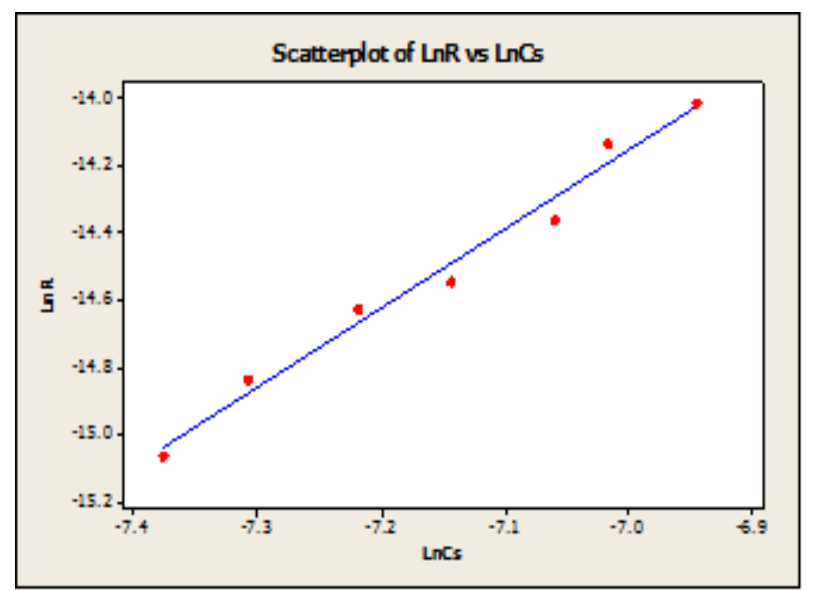

Figure 11. Regression Analysis: $L n R_{H D S}$ versus $\operatorname{Ln} C$ s for data obtained at $350^{\circ} \mathrm{C}, \mathrm{CAT}-2, \overline{\mathrm{Dp}}=0.356 \mathrm{~mm}, \mathrm{P}_{\mathrm{H} 2}=50 \mathrm{~atm}$

The regression equation is:

$$
\mathrm{LnR}=2.29+2.35 \mathrm{LnCs}
$$

The Vol. $\%$ of the product with boiling point from $\mathrm{C}_{5}$ to $210^{\circ} \mathrm{C}=4.3$ while the Vol. $\%$ of the product with boiling point $>210^{\circ} \mathrm{C}=89.9$ and the degrees API of the treated $=$ 12.8

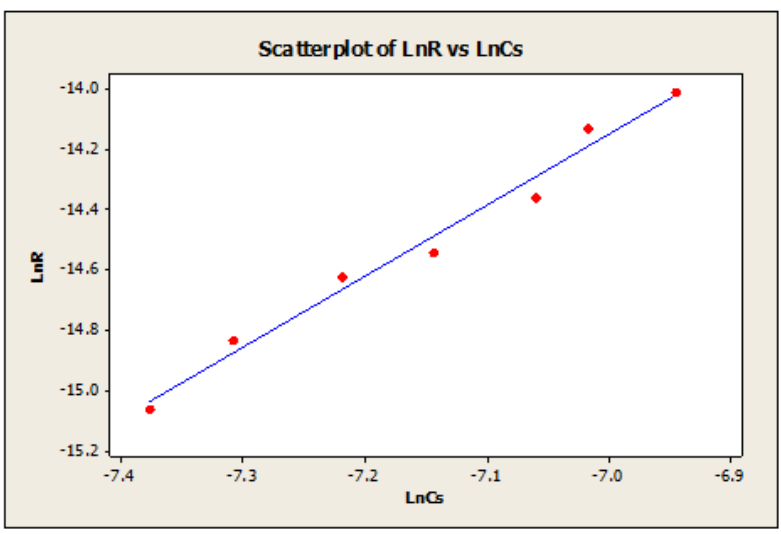

Figure 12. Regression Analysis: $L n R_{H D S}$ versus $L n$ Cs for data obtained at $380^{\circ} \mathrm{C}, \mathrm{CAT}-2, \overline{\mathrm{Dp}}=0.356 \mathrm{~mm}, \mathrm{P}_{\mathrm{H} 2}=50 \mathrm{~atm}$

The regression equation is

$$
\text { Ln. }=1.94+2.25 \mathrm{LnCs}
$$

The Vol. \% of the product with boiling point from $\mathrm{C}_{5}$ to $210^{\circ} \mathrm{C}=7.9$ while the Vol. $\%$ of the product with boiling point $>210^{\circ} \mathrm{C}=84.7$ and the degrees API of the treated product $=14.7$.

Due to the lack of Arrhenius equation for this catalyst, activity is investigated considering the recorded reaction rates of CAT- 1 and CAT -2 at $350^{\circ} \mathrm{C}$ and $380^{\circ} \mathrm{C}$, which showed that for the average reaction order with CAT-2 is $(2.35+2.25) / 2=2.3$, the corresponding specific reaction rates $\mathrm{k}_{1}$ at $350^{\circ} \mathrm{C}$ and $\mathrm{k}_{2}$ at $380^{\circ} \mathrm{C}$ are estimated applying reaction order $\mathrm{n}=2.3$ and found $\mathrm{k}_{1}=6.8833$ and $\mathrm{k}_{2}=10.0498$. These values compared with the corresponding values estimated for CAT $-1, \mathrm{k}_{1}=9.592$ at $\mathrm{T}=350^{\circ} \mathrm{C}$, and $\mathrm{k}_{2}=$ 13.695 at $\mathrm{T}=380^{\circ} \mathrm{C}$, show that the HDS activity of fresh CAT- 1 is higher than the activity of catalyst CAT-2 for the same particle sizes.

\section{Catalyst Activity and Performance with CAT-2:}

Pulverized particles $\overline{\mathrm{Dp}}=0.356 \mathrm{~mm}$, were used at $\mathrm{P}=50$ atm, $\mathrm{T}=350^{\circ} \mathrm{C}, \mathrm{C}_{\mathrm{S} 0}=14.633 * 10^{-4} \mathrm{~g}-\mathrm{mol} \mathrm{S} / \mathrm{cm}^{3}$ oil, $\mathrm{API}=9$, $\mathrm{LHSV}=2.6 \mathrm{~h}^{-1}$. Catalyst activity tests carried on CAT-2 samples for long periods up to 450 hours of operation are shown in Table 16. The relation between the attained conversion and catalyst age expressed in $\mathrm{ML}_{\text {oil }} / \mathrm{cm}_{\text {cat }}^{3}$ is presented in Figure 13.

Table 16. Chemical conversion attained vs. Catalyst age, $\mathrm{ML}_{\mathrm{oil}} / \mathrm{cm}_{\text {cat }}^{3}$

\begin{tabular}{|c|c|c|c|c|}
\hline $\begin{array}{c}\text { Catalyst } \\
\text { age MLoil } \\
\text { / } \mathrm{cm}^{3} \text { cat } \\
(10 \text { hours } \\
\text { daily })\end{array}$ & $\begin{array}{c}\text { Working } \\
\text { time, days }\end{array}$ & $\begin{array}{c}\text { Sulfur } \\
\text { content, } \mathrm{S} \\
\mathrm{wt} \%\end{array}$ & $\mathrm{X}_{\mathrm{f}} \%$ & $\begin{array}{c}\text { Relative } \\
\text { activity }= \\
\mathrm{X}_{\mathrm{f}} / \mathrm{X}_{0}\end{array}$ \\
\hline 6.6 & 1 & 2.51 & 46.02 & 1 \\
\hline 65.8 & 10 & 2.46 & 47.11 & 1.024 \\
\hline 98.7 & 15 & 2.46 & 47.12 & 1.024 \\
\hline 131.6 & 20 & 2.46 & 47.03 & 1.02 \\
\hline 164.5 & 25 & 2.55 & 45.12 & 0.98 \\
\hline 197.3 & 30 & 2.54 & 45.41 & 0.986 \\
\hline 230.2 & 35 & 2.56 & 45.05 & 0.979 \\
\hline 263.2 & 40 & 2.65 & 43.04 & 0.9352 \\
\hline 296.1 & 45 & 2.74 & 41.09 & 0.893 \\
\hline
\end{tabular}




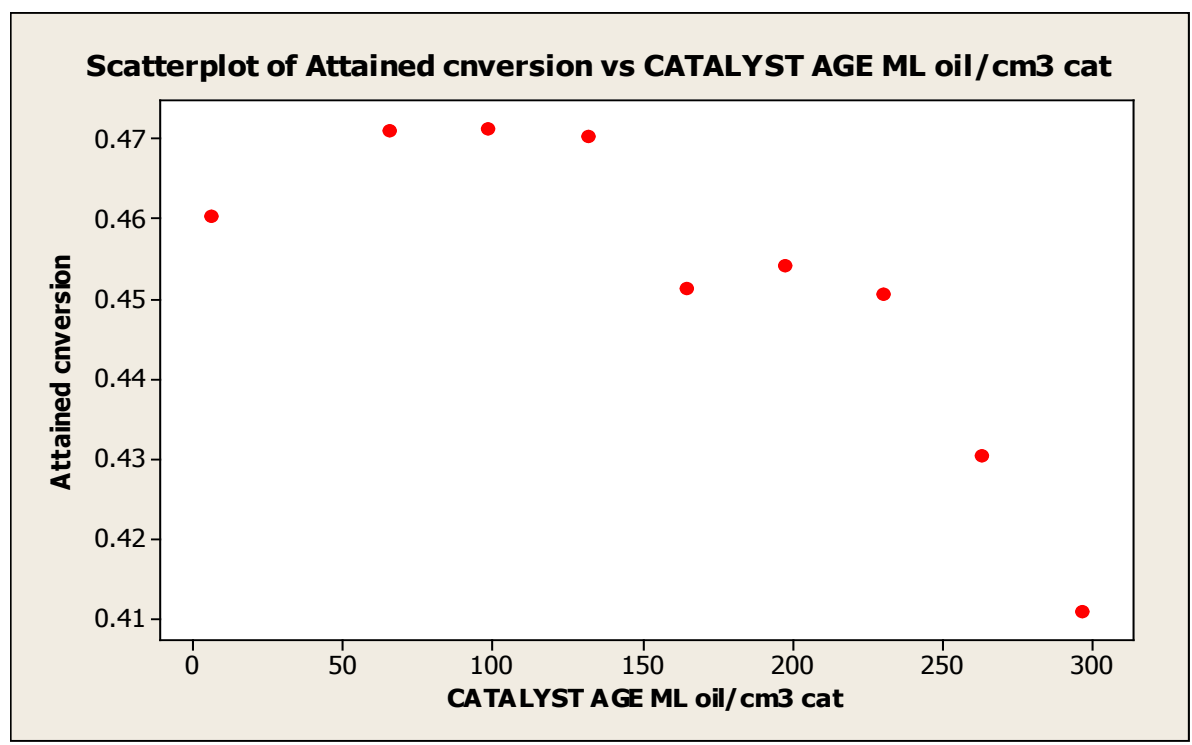

Figure 13. Chemical conversion attained conversion $X_{\mathrm{f}} \%$ vs. Catalyst age, MLoil $/ \mathrm{cm}^{3}$ cat, CAT-2

The activity tests showed that the activity increases slightly at the beginning of operation and is practically maintained constant during the first 200 working hours and that the sensible decrease in activity is observed after 300 hours. CAT-2 catalyst maintained $89.30 \%$ of its original activity after 450 hours of operation compared with the $80.4 \%$ maintained for CAT- 1 catalyst.

The results for both catalysts show that CAT-1 is $1.065 \%$ more active than CAT-2. The product analysis showed that more light products $(\mathrm{C} 1-\mathrm{C} 4)$ are obtained using CAT-1.

The results are shown in Table 17 and they show clearly that the presence of the molecular sieves incorporated in CAT-1 resulted in lighter products for the temperatures applied accompanied with increments in the API degrees.

Table 17. Hydro-treated Product analysis

\begin{tabular}{|c|c|c|c|c|}
\hline \multirow{2}{*}{ Catalyst sample } & \multicolumn{4}{|c|}{ Volume\% (product) } \\
\cline { 2 - 5 } & $\mathrm{C} 1-\mathrm{C} 4$ & $\mathrm{C} 5-210^{\circ} \mathrm{C}$ & $<210^{\circ} \mathrm{C}$ & API \\
\hline CAT-1, $\mathrm{T}=350^{\circ} \mathrm{C}$ & 6.5 & 6.3 & 87.2 & 13.2 \\
\hline CAT-2, $\mathrm{T}=350^{\circ} \mathrm{C}$ & 5.8 & 4.3 & 89.9 & 12.8 \\
\hline CAT-1, $\mathrm{T}=380^{\circ} \mathrm{C}$ & 9.5 & 8.9 & 81.6 & 15.6 \\
\hline CAT-2, $\mathrm{T}=380^{\circ} \mathrm{C}$ & 7.4 & 7.9 & 84.7 & 14.7 \\
\hline
\end{tabular}

Investigation on spent catalysts porous structure and chemical composition is very necessary, because it casts light on the best selection of the catalyst properties along with the reactor bed length and type of catalyst porous structure in every step during the Hydro-treatment. The reaction conditions indicated must be correlated with catalyst characteristics. Thus for heavy oil hydrotreatment, the application of an acidic catalyst must be accompanied with no high temperatures- severe conditions, where under high temperatures of operation the Hydro- Demetalization and Hydrogenation of Asphaltenes are more affected than
Hydrodesulphurization and Hydrodenitrogenation reactions. The operation under high temperatures will result in the thermal cracking of the large organometallic compounds as the Asphaltenes and others containing metals [23].

\section{Conclusions}

The prepared catalyst showed some comparable performance with some other industrial catalysts used for hydro-treating heavy oil residuum. The role of the working catalyst can be modified with some additives. MS 13X can be used to direct the reaction when necessary towards the hydrocracking path while maintaining the basic role of the hydro-desulfurization target. Hydrocracking products percentage increased with increasing the temperature of operation. More light lighter products are accompanied by higher API degrees.

The reactor type that implemented in this study proved to be a very useful type combining the performance of fixed bed plug flow reactor with complete back mixing performing as a CSTR eliminating mass and heat transfer resistances accompanying these processes. These features enabled reasonable determination of kinetic parameters. Catalyst particle size and intra- pellet mass transfer phenomena affecting reaction rate parameters are dependent on the properties of the applied catalyst, operating conditions and catalyst particle size.

\section{Acknowledgements}

Dr. Nader Okasha is gratefully thanked for his assistance in proofreading this article. 


\section{REFERENCES}

[1] M. S. Rana, V. Sa'mano, J. Ancheyta, J.A.I. Diaz, Fuel 86, 1216-1231, 2007.

[2] R.J. Farrauto and C.H. Bartholomew, "Fundamentals of Industrial Catalytic Processes", Blackie Academic \& Professional, London, 1997.

[3] L.Coulier, Hydrotreating model catalysts: from characterization to kinetics, Technische Universiteit Eindhoven, 166, 2001.

[4] Freedonia Group, Study No. 3217, pp 433, 12/2014.

[5] J.A. Rabo (1993) New Frontiers in Catalysis Proceedings 10th Int. Cong. on Catalysis, Budapest 19-24 July 1992.

[6] D. Sanfilippo, I.D. Miracca (2006) Dehydrogenation of paraffins: synergies between catalyst design and reactor engineering Cat. Today 111, 1-2, 133-139, 2006.

[7] A.N. Startsev,"The Mechanism of HDS Catalysis", Catal. Rev.-Sci. Eng. 37, 353, 1995.

[8] M.Zdražil, M.Kraus., Studies in Surface Science and Catalysis" Vol. 27, 257-276, 1986.

[9] H. Schulz, M. Schon and N. Rahman, Stud. Surf. Sci. Catal. 27, 201 (1986).

[10] J.M.J.G. Lipsch and G.C.A. Schuit, J. Catal. 15, 179 (1969).

[11] B.T. Carvill and M.J. Thompson, Appl. Catal. 75, 249 (1991). Introduction 22.
[12] J.M. Ammus, Ph.D. Thesis, National Technical University of Athens, 1985.

[13] I.A. van Parijs and G.F. Froment, Ind. Eng. Chem. Prod. Res. Dev. 25, 431 (1986).

[14] M. Daage and R.R. Chianelli, J. Catal. 149, 414 (1994).

[15] Nino Rinaldi, Masahiro Yoshioka, Takeshi Kubta, and Yasuaki OK, Journal of the Japan Petroleum Institute, 53, (5), 292-302 (2010).

[16] Rinaldi, N., Kubota, T., Okamoto, Y., Appl. Catal. A: General, 374, 228 (2010).

[17] Rinaldi, N., Kubota, T., Okamoto, Y., Ind. Eng. Chem. Res., 48, 10414 (2009).

[18] Usman, T. Kubota, Y. Araki, K. Ishida, Y. Okamoto, J. Catal. 2004, 227, 523-529.

[19] Usman, M. Takaki, T. Kubota, Y. Okamoto, Appl. Catal. A $2005,286,148-154$.

[20] Hamid A. Al-Megren*, the Arabian Journal for Science and Engineering, Volume 34, Number 1A, 55, January 2009.

[21] G.Muralidhar, F.E.Massoth, JosephShabtai, "Catalytic functionalities of supported sulfides: I. Effect of support and additives on the CoMo catalyst", Journal of Catalysis, Volume 85, Issue 1, 44-55, January 1984.

[22] Octave Levenspiel, Chemical reaction engineering, John Wiley \& sons, 1999.

[23] Mohan S. Rana, J.Ancheyta, S.K.Maity, P. Rayo, Catalysis Today, Vol.130, Issues 2-4, 30-Jan 2008, 411-420. 